\title{
SISTEM PAKAR PENELUSURAN KECERDASAN PADA ANAK DENGAN MENGGUNAKAN METODE FORWARD CHAINING
}

\author{
Oleh : \\ Deci Irmayani \\ Dosen Prodi Manajemen Informatika, AMIK Labuhanbatu \\ Rantauprapat, Medan; deci irmayani1@gmail.com
}

\begin{abstract}
Artificial Intelligence(Artificial Intelligence) as the intelligence displayed by an artificial entity. Intelligence was create and out into a machine(computer) in order to perform expert work as humans. Expert systems area branch of AI that makes use of a special knowledge for problem resolution. Are included into the psychology of child development as well as changes in every aspect of the development is also related to determinants (determinant factors) that influence the genetic and environmental factors. Children's intelligence expert system is used search Forward Chaining method which is a method that performs inference techniques of reasoning toward a conclusion that there is a problem from the facts that occurred. Tracking system that uses intelligence in children is quite in accordance with the method of forward chaining. This is evident by the absence of significant barriers in the preparation of this system, and the resulting knowledge system is also in accordance with the manual search.
\end{abstract}

Keyword : Forward Chaining, Expert System, AI.

\section{PENDAHULUAN}

Kecerdasan Buatan (Artificial Intelligence) didefinisikan sebagai kecerdasan yang ditunjukkan oleh suatu entitas buatan. Kecerdasan diciptakan dan dimasukkan ke dalam suatu mesin (komputer) agar dapat melakukan kerjaan pakar seperti yang dapat dilakukan manusia. Sistem pakar adalah salah satu cabang dari AI yang membuat penggunaan secara luas knowledge yang khusus untuk penyelesaian masalah. Seorang pakar adalah orang yang mempunyai keahlian dalam bidang tertentu, yaitu pakar yang mempunyai knowledge atau kemampuan khusus yang orang lain tidak mengetahui atau mampu dalam bidang yang dimilikinya (Hersatoto Listiyono, 2008). Sistem pakar adalah sebuah program komputer yang biasanya terdiri dari beberapa pengetahuan, mesin referensi dan user-interface ( Kr.Sarma, Singh, 2006)

Salah satu pemanfaatan sistem pakar digunakan pada ilmu kesehatan,mengingat pandangan masyarakat terhadap pola kecerdasan anak belakangan ini semakin peka dan banyaknya orang tua yang tidak memperhatikan perkembangan anaknya. Oleh karena itu kita membutuhkan seorang psikolog,di mana mereka mengerti tentang ilmu perilaku manusia dalam hubungan timbal balik dengan lingkungannya. Yang termasuk kedalam psikologi perkembangan anak disamping perubahan setiap aspek perkembangan juga berkaitan dengan faktor-faktor penentu (determinant factors) yang mempengaruhinya yaitu faktor genetika dan lingkungan (Syamsu Yusuf LN, 2012).

Adapun faktor yang mempengaruhi kualitas kecerdasan adalah :

1. Faktor genetika (keturunan)

2. Faktor lingkungan.

Seorang anak dapat mengembagkan berbagai kecerdasan jika mempunyai faktor keturunan dan dirangsang oleh lingkungan terus menerus. Orang tua yang cerdas anaknya cenderung akan cerdas pula jika faktor lingkungan mendukung pengembangan kecerdasannya sejak di dalam kandungan,masa bayi dan balita. Walaupun kedua orang tuanya cerdas tetapi jika lingkungannya tidak menyediakan kebutuhan pokok untuk pengembangan kecerdasannya,maka potensi kecerdasan anak tidak akan berkembang optimal. Sedangkan orang tua yang kebetulan tidak berkesempatan mengikuti pendidikan tinggi (belum tentu mereka tidak cerdas,mungkin karena tidak ada kesempatan atau hambatan ekonomi) 
anaknya bisa cerdas jika dicukupi kebutuhan untuk pengembangan kecerdasan sejak di dalam kandungan sampai usia sekolah dan remaja. Pada Sistem pakar penelusuran kecerdasan anak ini digunakan metode Forward Chaining yang merupakan metode teknik inferensi yang melakukan penalaran dari suatu masalah menuju konklusi yang terdapat dari fakta yang terjadi.

Pedoman dalam mempelajari kecerdasan pada anak itulah yang dapat dibuat sebagai bagian dari bentuk kecerdasan buatan yang diimplementasikan dalam suatu sistem pakar. Oleh karena itu penulis mengambil judul tesis

"Sistem Pakar Penelusuran Kecerdasan Pada Anak Dengan Menggunakan Metode Forward Chaining". Pembuatan aplikasi sistem pakar ini untuk menelusuri kecerdasan pada anak,sehingga didapatkan suatu hasil analisa yang diakui tingkat keakuratannya. Pembuatan aplikasi sistem pakar pada penulisan ini menggunakan bantuan bahasa pemrograman PHP.

\section{PERMASALAHAN}

Permasalahan yang dibahas dari latar belakang di atas adalah :

1. Bagaimana membangun sistem pakar untuk penelususran kecerdasan pada anak dengan menggunakan metode Forward Chaining

2. Bagaimana mensimulasikan penentuan makanan bergizi dalam bentuk Rule.

\section{LANDASAN TEORI}

\section{Definisi Sistem Pakar}

Secara umum, sistem pakar (expert system) adalah sistem yang berusaha mengadopsi pengetahuan manusia ke komputer, agar komputer dapat menyelesaikan masalah seperti yang biasa dilakukan oleh para ahli. Sistem pakar yang baik dirancang agar dapat menyelesaikan suatu permasalahan tertentu dengan meniru kerja dari para ahli (Sri Kusumadewi, 2003). Sistem pakar juga merupakan suatu bidang teknik kecerdasan yang paling popular sekarang ini. Sistem pakar (Expert System) adalah salah satu bagian ilmu komputer yang membuat agar mesin (komputer) dapat melakukan pekerjaan seperti dan sebaik yang dilakukan oleh manusia ( Feri Fahrur Rohman, Ami Fauzijah, 2008).

Seorang pakar adalah orang yang mempunyai keahlian dalam bidang tertentu,yaitu pakar yang mempunyai knowledge atau kemampuan khusus yang orang lain tidak emngetahui atau mampu dalam bidang yang dimilikinya (Hersatoto Listiyono, 2008).

\section{Struktur Sistem Pakar}

Sistem pakar disusun oleh dua bagian utama, yaitu lingkungan pengembangan (development environment) dan lingkungan konsultasi (consultation environment) (Turban, 2006). Lingkungan pengembangan sistem pakar digunakan untuk memasukkan pengetahuan pakar ke dalam lingkungan sistem pakar, sedangkan lingkungan konsultasi digunakan oleh pengguna yang bukan pakar guna memperoleh pengetahuan pakar. Komponen-komponen sistem pakar dalam dua bagian tersebut dapat dilihat pada Gambar 2.1. Komponen-komponen yang terdapat dalam sistem pakar adalah seperti yang terdapat pada Gambar 2.1, yaitu User Interface (antarmuka pengguna), basis pengetahuan, akuisisi pengetahuan, mesin inference, workplace, fasilitas penjelasan, perbaikan pengetahuan (Feri Fahrur Rohman, Ami Fauzijah, 2008). 
Lingkungan Konsultasi

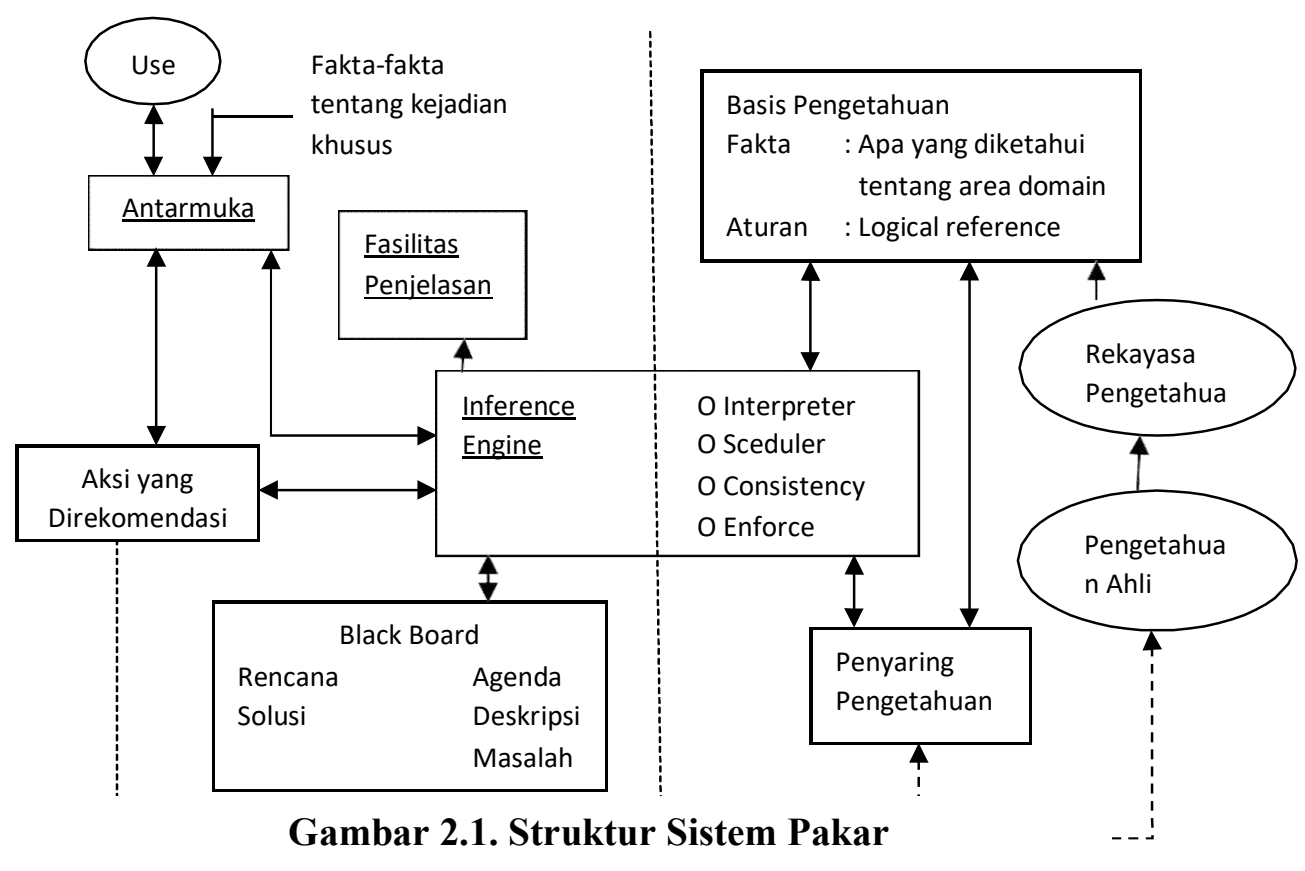

Seorang pakar mempunyai pengetahuan tentang masalah yang khusus. Dalam hal ini disebut domain knowledge. Penggunaan kata "domain" untuk memberikan penekanan pengetahuan pada problem yang spesifik. Pakar menyimpan domain knowledge pada Long Term Memory (LTM) atau ingatan jangka panjangnya.

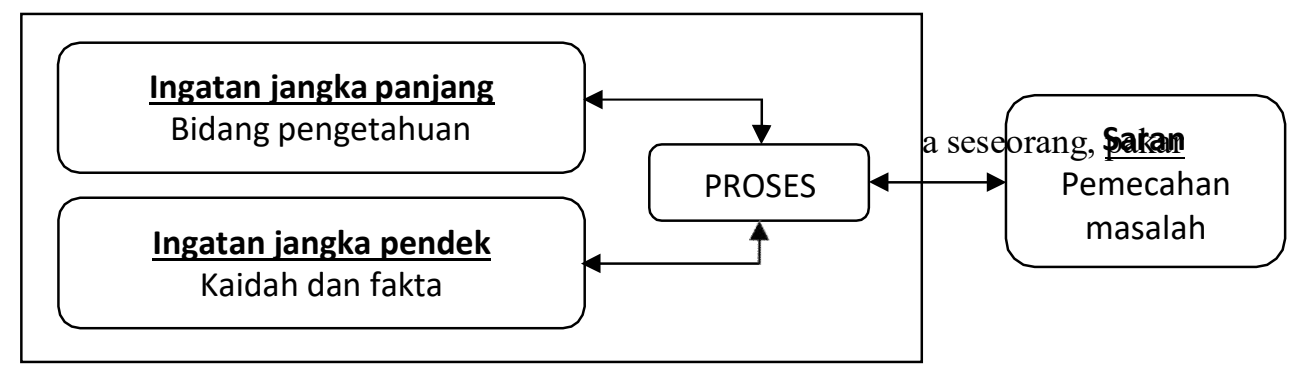

terlebih dahulu mer

Gambar 2.2. Pemecahan Masalah Pada Pakar

$t$ Term Memory (STM) atau ingatan jangka pendek. Kemudian pakar memberikan solusi tentang masalah tersebut dengan mengkombinasikan fakta-fakta pada STM dengan pengetahuan LTM. Dengan menggunakan proses ini pakar mendapatkan informasi baru dan sampai pada kesimpulan masalah. Gambar 2.2 menunjukkan berkas diagram pemecahan masalah dengan pendekatan yang digunakan pakar.

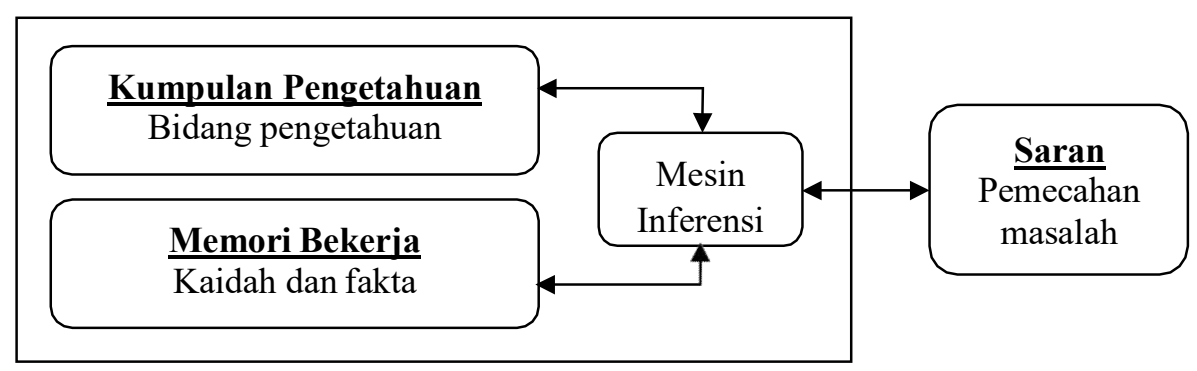

Gambar 2.3. Struktur Pemecahan Masalah Pada Sistem 
Sistem pakar dapat memecahkan masalah menggunakan proses yang sama dengan metode yang digunakan oleh pakar, struktur yang digunakan ditunjukkan pada Gambar 3 ( Feri Fahrur Rohman, Ami Fauzijah, 2008).

\section{Pelacakan ke Depan (forward chaining)}

Metode forward chaining adalah metode pencarian atau teknik pelecakan ke depan yang dimulai dengan informasi yang ada dan penggabungan rule untuk menghasilkan suatu kesimpulan atau tujuan (Russel P, 2003).

Pelacakan ke depan adalah pendekatan yang dimotori data (data-driven). Dalam pendekatan ini pelacakan dimulai dari informasi masukan, dan selanjutnya mencoba menggambarkan kesimpulan. Pelacakan ke depan, mencari fakta yang sesuai dengan bagian $I F$ dari aturan IF-THEN. Gambar 5 menunjukkan proses forward chaining.

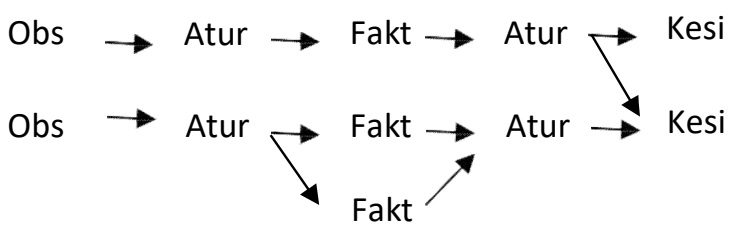

\section{Gambar 2.5 Forward Chaining}

Langkah-langkah yang harus dilakukan dalam membuat sistem forward chaining (Riskadewi dan Antonius Hendrik, 2005) berbasis aturan:

1. Pendefinisian masalah, tahap ini meliputi pemilihan domain masalah dan akusisi pengetahuan.

berikut :
2. Pendefinisian data input, yaitu sistem forward chaining memerlukan data awal untuk memulai inferensi.

3. Pendefinisian struktur pengendalian data, yaitu aplikasi yang kompleks memerlukan aturan tambahan untuk membantu pengaktifan aturan.

4. Penulisan kode awal, yaitu untuk menentukan efektifitas pengetahuan sistem dalam struktur aturan yang baik.

5. Pengujian sistem, yaitu dilakukan dengan beberapa aturan untuk menguji sejauh mana sistem berjalan dengan benar.

6. Perancangan antarmuka, dibuat bersamaan dengan pembuatan basis knowledge.

7. Pengembangan sistem, yaitu meliputi penambahan antar muka dan pengetahuan sesuai dengan prototipe sistem.

8. Evaluasi sistem, pada tahap ini dilakukan pengujian sistem dengan masalah yang sebenarnya. Jika sistem belum berjalan dengan baik maka akan dilakukan pengembangan kembali.

\section{PEMBAHASAN}

\section{Arsitektur Sistem Pakar}

Sesuai dengan bentuk arsitektur sistem pakar pada landasan teori, dengan melakukan penyederhanaan di beberapa komponen, maka arsitektur sistem pakar untuk menentukan kecerdasan pada anak dapat didesain seperti 


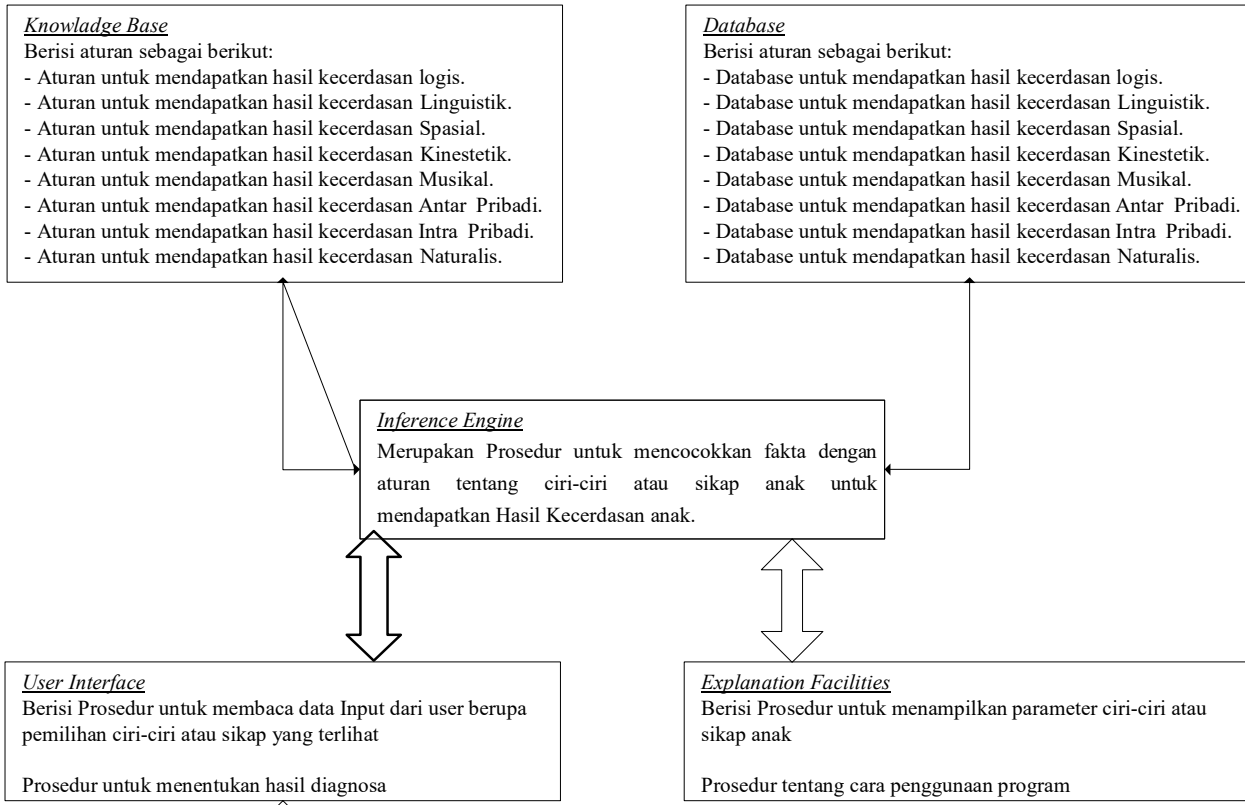

\section{Cara Representasi Pengetahuan}

Dalam penelitian menentukan kecerdasan anak ini teknik yang cocok di pakai adalah Forward Chaining. Pemilihan metode ini didasari karena metode ini cocok diterapkan untuk mendapatkan hasil konsultasi dari beberapa ciri-ciri yang dimiliki si anak. Kaidah yang digunakan adalah jika-maka (if-then). Bagian premis dalam aturan produksi dapat memiliki lebih dari satu proposisi yaitu berarti pada sistem pakar ini dalam satu kaidah dapat memiliki lebih dari satu ciri-ciri. Ciri-ciri tersebut dihubungkan dengan menggunakan operator logika DAN. Bentuk pernyataannya adalah:

Adapun contoh kaidah sistem pakar menentukan kecerdasan anak di bawah lima tahun adalah sebagai berikut:

IF Mempunyai kosakata yang luas untuk anak seusianya (A19)

AND Mengarang kisah khayal atau menuturkan lelucon saat cerita (A21)

$\boldsymbol{A N D}$ Mengeja kata-kata dengan tepat dan mudah (A22)

THEN Kecerdasan Linguistik (K1)

IF Ahli bermain dam, monopoli, atau permainan srtategi yang lain (A1)
AND Mengajukan pertanyaan seperti "Dimana akhir alam semesta?" atau "mengapa langit biru?" (A20)

AND Menghitung problem aritmatika dengan cepat di luar kepala (A23)

THEN Kecerdasan Logis (K2)

IF Lebih banyak memahami lewat gambar daripada lewat kata-kata ketika sedang membaca (A12)

AND Memberikan gambaran visual yang jelas ketika sedang memikirkan sesuatu (A14)

AND kontruksi tiga dimensi yang menarik

(A15)

THEN Kecerdasan Spasial (K3)

IF Bergerak-gerak ketika sedang duduk (A7)

AND Berprestasi dalam olahraga kompetitif di sekolah atau lingkungan (A9)

AND Memperlihatkan keterampilan dalm bidang kerajinan tangan (A17)

THEN Kecerdasan Kinestetik (K4) 
IF Bisa mengikuti irama (A11)

AND Memiliki suara yang bagus untuk menyanyi atau baca Al Qur'an (A16)

AND Mudah mengingat lagu (A24)

THEN Kecerdasan Kinestetik(K5)

IF Bisa mengikuti irama (A11)

$\boldsymbol{A N D}$ Memiliki suara yang bagus untuk menyanyi atau baca Al Qur'an (A16)

$\boldsymbol{A N D}$ Mudah mengingat lagu (A24)

THEN Kecerdasan Musikal (K5)

IF Banyak bersosialisasi di sekolah atau lingkungan tempat tinggalnya (A3)

$\boldsymbol{A N D}$ Berempati besar terhadap perasaan orang lain (A6)

pertikaian (A8)

$\boldsymbol{A N D}$ sebagai "penengah" ketika terjadi

THEN Kecerdasan Antar Pribadi (K6)

IF Bekerja atau belajar dengan baik seorang diri (A4)

AND Belajar dari kesalahan masalalu (A5)

$\boldsymbol{A N D}$ Bersikap realistis terhadap kekuatan dan kelemahannya (A10)

THEN Kecerdasan Intra Pribadi (K7)

IF Akrab dengan hewan peliharaan (A2) $\boldsymbol{A N D}$ Membawa pulang serangga, bunga, daun, atau benda-benda alam lain untuk diperlihatkan kepada anggota keluarga (A13)

AND Memperlihatkan pemahaman yang mendalam di sekolah dalam topik-topik yang melibatkan sistem kehidupan (misalnya topik biologi) (A18)

THEN Kecerdasan Naturalis (K8) domain tertentu. Pendekatan basis pengetahuan yang dilakukan adalah penalaran berbasis pengetahuan (Rule-Based Reasoning) dimana pengetahuan direpresentasikan dengan menggunakan aturan berb entuk : IF-THEN.

Pada penalaran berbasis pengetahuan, penyelesaian masalah dapat diselesaikan secara berurutan dimana teknik yang digunakan adalah forward chaining yaitu dengan melakukan penelusuran dari rule pertama sampai rule terakhir. Adapun fakta dan aturan penelusuran dalam menentukan kecerdasan anak dapat dilihat pada aturan-aturan pada table 4.1 berikut.

\section{Knowledge Base}

Basis Pengetahuan berisi pengetahuanpengetahuan dalam penyelesaian masalah didalam

Tabel 4.1. Basis Pengetahuan Sifat-Sifat Khususnya

\begin{tabular}{|c|l|c|}
\hline $\begin{array}{c}\text { Kode } \\
\text { Ciri-Ciri }\end{array}$ & \multicolumn{1}{|c|}{ Ciri-Ciri } & \multirow{2}{*}{ Kecerdasan } \\
\hline \multirow{3}{*}{ K1 } & Mempunyai kosakata yang luas untuk anak seusianya & \multirow{2}{*}{$\begin{array}{c}\text { Kecerdasan } \\
\text { Linguistik }\end{array}$} \\
\cline { 2 - 2 } & Mengarang kisah khayal atau menuturkan lelucon saat cerita & \\
\cline { 2 - 3 } & Mengeja kata-katadengan tepat dan mudah & \\
\hline
\end{tabular}




\begin{tabular}{|c|c|c|}
\hline \multirow{3}{*}{$\mathbf{K 2}$} & Ahli bermain dam, monopoli, atau permainan srtategi yang lain & \multirow{3}{*}{$\begin{array}{l}\text { Kecerdasan } \\
\text { Logis }\end{array}$} \\
\hline & $\begin{array}{l}\text { Mengajukan pertanyaan seperti "Dimana akhir alam semesta?" atau } \\
\text { "mengapa langit biru?" }\end{array}$ & \\
\hline & Menghitung problem aritmatika dengan cepat di luar kepala & \\
\hline \multirow{3}{*}{$\mathbf{K 3}$} & $\begin{array}{l}\text { Lebih banyak memahami lewat gambar daripada lewat kata-kata } \\
\text { ketika sedang membaca }\end{array}$ & \multirow{3}{*}{$\begin{array}{l}\text { Kecerdasan } \\
\text { Spasial }\end{array}$} \\
\hline & $\begin{array}{l}\text { Memberikan gambaran visual yang jelas ketika sedang memikirkan } \\
\text { sesuatu }\end{array}$ & \\
\hline & Membuat kontruksi tiga dimensi yang menarik & \\
\hline \multirow{3}{*}{ K4 } & Bergerak-gerak ketika sedang duduk & \multirow{3}{*}{$\begin{array}{l}\text { Kecerdasan } \\
\text { Kinestetik }\end{array}$} \\
\hline & Berprestasi dalam olahraga kompetitif di sekolah atau lingkungan & \\
\hline & Memperlihatkan keterampilan dalm bidang kerajinan tangan & \\
\hline \multirow{3}{*}{ K5 } & Bisa mengikuti irama & \multirow{3}{*}{$\begin{array}{l}\text { Kecerdasan } \\
\text { Musikal }\end{array}$} \\
\hline & Memiliki suara yang bagus untuk menyanyi atau baca $\mathrm{Al}$ Qur'an & \\
\hline & Mudah mengingat lagu & \\
\hline \multirow{3}{*}{ K6 } & Banyak bersosialisasi di sekolah atau lingkungan tempat tinggalnya & \multirow{3}{*}{$\begin{array}{l}\text { Kecerdasan } \\
\text { Antar Pribadi }\end{array}$} \\
\hline & Berempati besar terhadap perasaan orang lain & \\
\hline & Berperan sebagai "penengah" ketika terjadi pertikaian & \\
\hline \multirow{3}{*}{ K7 } & Bekerja atau belajar dengan baik seorang diri & \multirow{3}{*}{$\begin{array}{l}\text { Kecerdasan } \\
\text { Intra Pribadi }\end{array}$} \\
\hline & Belajar dari kesalahan masa lalu & \\
\hline & Bersikap realistis terhadap kekuatan dan kelemahannya & \\
\hline K8 & Akrab dengan hewan peliharaan & $\begin{array}{l}\text { Kecerdasan } \\
\text { Naturalis }\end{array}$ \\
\hline
\end{tabular}

Membawa pulang serangga, bunga, daun, atau benda-benda alam lain untuk diperlihatkan kepada anggota keluarga

Memperlihatkan pemahaman yang mendalam di sekolah dalam topiktopik yang melibatkan sistem kehidupan (misalnya topik biologi)

\section{DataBase}

Proses perancangan sistem membutuhkan suatu database yang digunakan untuk menyimpan data dan informasi yang diperlukan dalam sistem dan disusun sedemikian rupa ke dalam bentuk tabel untuk mempermudah sistem dalam mengambil keputusan. Database yang digunakan adalah MySql 
dengan nama databasenya dbpakar. Seluruh tabel saling berhubungan dengan yang lainnya dan gambaran tabel basis pengetahuan yang digunakan adalah sebagai berikut:

\section{Tabel admin}

Tabel admin ini merupakan simpan data bagi admin yang akan login ke server. Hanya admin yang berhak menambah, mengedit dan menghapus data yang ada pada sistem. Dalam tabel admin ada dua field, yaitu:

Tabel 4.2 Tabel Admin

\begin{tabular}{|c|l|c|c|c|}
\hline No & \multicolumn{1}{|c|}{$\begin{array}{c}\text { Field } \\
\text { Name }\end{array}$} & $\begin{array}{c}\text { Data } \\
\text { Type }\end{array}$ & $\begin{array}{c}\text { Field } \\
\text { Size }\end{array}$ & Keterangan \\
\hline 1. & user_login & varchar & 15 & $\begin{array}{c}\text { Primary } \\
\text { key }\end{array}$ \\
\hline 2. & Nama & varchar & 30 & \\
\hline 3. & Password & varchar & 50 & \\
\hline
\end{tabular}

3. Tabel kecerdasan

Tabel kecerdasan ini merupakan tempat menyimpan input data dari delapan kecerdasan yang akan menjadi hasil akhir dari proses ciriciri. Tabel kecerdasan ini memiliki dua field, yaitu:

Tabel 4.3 Tabel Kecerdasan

\begin{tabular}{|c|c|c|c|c|}
\hline $\begin{array}{c}\mathrm{N} \\
\mathrm{O}\end{array}$ & Field Name & $\begin{array}{c}\text { Data } \\
\text { Type }\end{array}$ & $\begin{array}{c}\text { Fiel } \\
\mathrm{d} \\
\text { Size }\end{array}$ & $\begin{array}{c}\text { Keteranga } \\
\mathrm{n}\end{array}$ \\
\hline 1 & $\begin{array}{l}\text { kd_kecerdasa } \\
\mathrm{n}\end{array}$ & Char & 3 & $\begin{array}{c}\text { Primary } \\
\text { key }\end{array}$ \\
\hline 2 & $\begin{array}{l}\mathrm{nm} \\
\text { an kecerdas }\end{array}$ & $\begin{array}{c}\text { varcha } \\
\mathrm{r}\end{array}$ & 30 & \\
\hline
\end{tabular}

\section{Tabel ciri}

Tabel ciri ini merupakan tabel untuk menyimpan ciri-ciri yang akan menentukan kecerdasan yang dimiliki oleh si anak. Tabel ciri memiliki empat field, yaitu:

Tabel 4.4 Tabel Ciri

\begin{tabular}{|c|c|c|c|c|}
\hline $\mathrm{N}$ & Field Name & $\begin{array}{c}\text { Data } \\
\text { Type }\end{array}$ & $\begin{array}{c}\text { Fiel } \\
\mathrm{d}\end{array}$ & $\begin{array}{c}\text { Keteranga } \\
\text { Size }\end{array}$ \\
& & & & \\
\hline
\end{tabular}

\begin{tabular}{|c|l|c|c|c|}
\hline 1 & id_ciri & $\begin{array}{c}\text { Intege } \\
\mathrm{r}\end{array}$ & 3 & $\begin{array}{c}\text { Primary } \\
\text { key }\end{array}$ \\
\hline 2 & kd_ciri & Char & 3 & \\
\hline 3 & nm_ciri & $\begin{array}{c}\text { varcha } \\
\mathrm{r}\end{array}$ & 100 & \\
\hline 4 & $\begin{array}{l}\text { kd_kecerdasa } \\
\mathrm{n}\end{array}$ & Char & 3 & \\
\hline
\end{tabular}

4. Tabel hasil

Tabel hasil ini merupakan tabel dari hasil proses rule yang ada dalam sistem, yang ambil dari empat ciri-ciri yang dimiliki oleh si anak. Tabel hasil ini memiliki lima field, yaitu:

Tabel 4.5 Tabel Hasil

\begin{tabular}{|c|c|c|c|c|}
\hline $\begin{array}{c}\mathrm{N} \\
\mathrm{o}\end{array}$ & Field Name & $\begin{array}{l}\text { Data } \\
\text { Type }\end{array}$ & $\begin{array}{c}\text { Fiel } \\
\mathrm{d} \\
\text { Size }\end{array}$ & $\begin{array}{c}\text { Keteranga } \\
\mathrm{n}\end{array}$ \\
\hline 1 & id_hasil & $\begin{array}{c}\text { Intege } \\
\mathrm{r}\end{array}$ & 5 & $\begin{array}{c}\text { Primary } \\
\text { key }\end{array}$ \\
\hline 2 & Tgl & Date & & \\
\hline 3 & $\begin{array}{l}\text { kd_kecerdasa } \\
\mathrm{n}\end{array}$ & $\begin{array}{c}\text { Intege } \\
\mathrm{r}\end{array}$ & 1 & \\
\hline 4 & user_login & $\begin{array}{c}\text { varcha } \\
\text { r }\end{array}$ & 15 & \\
\hline
\end{tabular}

5. Tabel Pengunjung atau Tabel Anak

Tabel pengunjung merupakan tabel untuk menyimpan data pengunjung yang pernah registrasi dan menggunakan sistem ini. Tabel pengunjung ini memiliki delapan field, yaitu:

Tabel 4.6 Tabel Rule

\begin{tabular}{|c|l|c|c|l|}
\hline No & \multicolumn{1}{|c|}{$\begin{array}{c}\text { Field } \\
\text { Name }\end{array}$} & $\begin{array}{c}\text { Data } \\
\text { Type }\end{array}$ & $\begin{array}{c}\text { Field } \\
\text { Size }\end{array}$ & Keterangan \\
\hline 1 & user_login & varchar & 15 & user_login \\
\hline 2 & Nama & varchar & 30 & \\
\hline 3 & tmp_lahir & varchar & 50 & \\
\hline 4 & tgl_lahir & Date & & \\
\hline 5 & nm_ortu & varchar & 30 & \\
\hline 6 & Pekerjaan & varchar & 30 & \\
\hline
\end{tabular}




\begin{tabular}{|c|l|c|c|l|}
\hline 7 & Alamat & varchar & 50 & \\
\hline 8 & Password & varchar & 50 & \\
\end{tabular}

Inference Engine

Motor Inferensi (Inference engine) merupakan pusat pengambilan keputusan pada

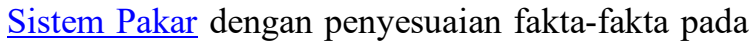
memori dengan basis pengetahuan untuk mendapatkan kesimpulan dan jawaban. Inference engine merupakan otak dan pemikir dari suatu Sistem Pakar. Dalam inference engine ini sistem melakukan suatu penalaran yang dilandasi oleh basis pengetahuan (didapat dari pakar) yang dimiliki sistem sehingga menghasilkan sebuah keputusan.

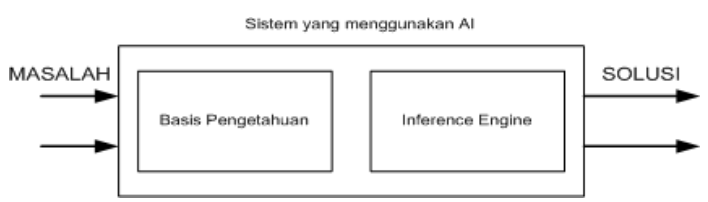

\section{Gambar 4.2 Sistem Artificial Intelegence}

Proses penalaran ada dua macam dan biasanya lebih disebut dengan proses chaining (forward chaining dan backward chaining). Kedua metode ini mempunyai kelebihan tersendiri, semuanya itu tergantung terutama dari kondisi permasalahan yang dihadapi dan basis pengetahuan.

Inference Engine berisi prosedur-prosedur untuk pencocokan fakta dengan aturan dan hasil, juga berisi prosedur atau langkah pertama dalam membangun inference engine dalam menentukan kecerdasan anak, ciri-ciri yang dimiliki sebagai berikut :

Tabel 4.7 Ciri-Ciri Pada Anak

\begin{tabular}{|c|c|}
\hline Kode & Ciri-ciri atau sikap anak \\
\hline A1 & Ahli bermain dam, monopoli, atau permainan srtategi yang lain \\
\hline $\mathbf{A 2}$ & Akrab dengan hewan peliharaan \\
\hline $\mathbf{A 3}$ & Banyak bersosialisasi di sekolah atau lingkungan tempat tinggalnya \\
\hline A4 & Bekerja atau belajar dengan baik seorang diri \\
\hline $\mathbf{A 5}$ & Belajar dari kesalahan masa lalu \\
\hline A6 & Berempati besar terhadap perasaan orang lain \\
\hline A7 & Bergerak-gerak ketika sedang duduk \\
\hline $\mathbf{A 8}$ & Berperan sebagai "penengah" ketika terjadi pertikaian \\
\hline A9 & Berprestasi dalam olahraga kompetitif di sekolah atau lingkungan \\
\hline $\mathbf{A 1 0}$ & Bersikap realistis terhadap kekuatan dan kelemahannya \\
\hline A11 & Bisa mengikuti irama \\
\hline A12 & $\begin{array}{l}\text { Lebih banyak memahami lewat gambar daripada lewat kata-kata ketika sedang } \\
\text { membaca }\end{array}$ \\
\hline A13 & $\begin{array}{l}\text { Membawa pulang serangga, bunga, daun, atau benda-benda alam lain untuk } \\
\text { diperlihatkan kepada anggota keluarga }\end{array}$ \\
\hline A14 & Memberikan gambaran visual yang jelas ketika sedang memikirkan sesuatu \\
\hline
\end{tabular}




\begin{tabular}{|c|l|}
\hline $\mathbf{A 1 5}$ & Membuat kontruksi tiga dimensi yang menarik \\
\hline $\mathbf{A 1 6}$ & Memiliki suara yang bagus untuk menyanyi atau baca Al Qur'an \\
\hline $\mathbf{A 1 7}$ & Memperlihatkan keterampilan dalm bidang kerajinan tangan \\
\hline $\mathbf{A 1 8}$ & $\begin{array}{l}\text { Memperlihatkan pemahaman yang mendalam di sekolah dalam topik-topik yang } \\
\text { melibatkan sistem kehidupan (misalnya topik biologi) }\end{array}$ \\
\hline $\mathbf{A 1 9}$ & Mempunyai kosakata yang luas untuk anak seusianya \\
\hline $\mathbf{A 2 0}$ & $\begin{array}{l}\text { Mengajukan pertanyaan seperti "Dimana akhir alam semesta?" atau "mengapa } \\
\text { langit biru?" }\end{array}$ \\
\hline $\mathbf{A 2 1}$ & Mengarang kisah khayal atau menuturkan lelucon saat cerita \\
\hline $\mathbf{A 2 2}$ & Mengeja kata-katadengan tepat dan mudah \\
\hline $\mathbf{A 2 3}$ & Menghitung problem aritmatika dengan cepat di luar kepala \\
\hline $\mathbf{A 2 4}$ & Mudah mengingat lagu \\
\hline
\end{tabular}

1. Alur Informasi Menentukan Kecerdasan Linguistik

Aturan untuk mendapatkan Kecerdasan Linguistik seperti gambar dibawah ini :

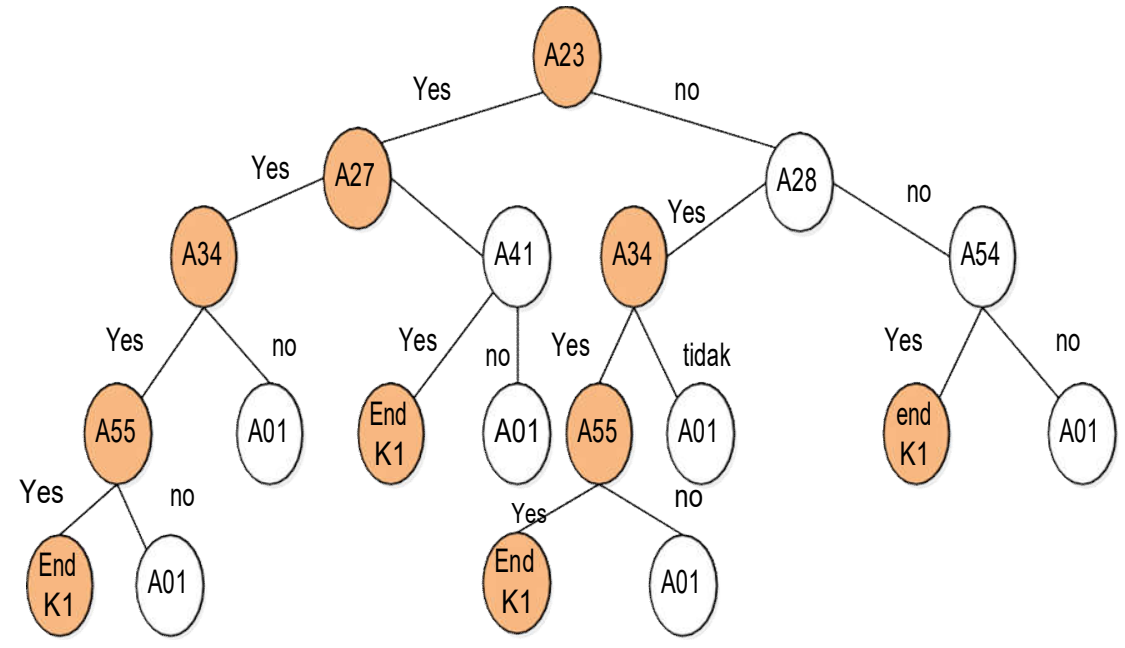

Gambar 4.3 Alur Informasi Kecerdasan Linguistik

2. Alur Informasi Menentukan Kecerdasan Logis

Aturan untuk mendapatkan Kecerdasan Logis seperti gambar dibawah ini : 


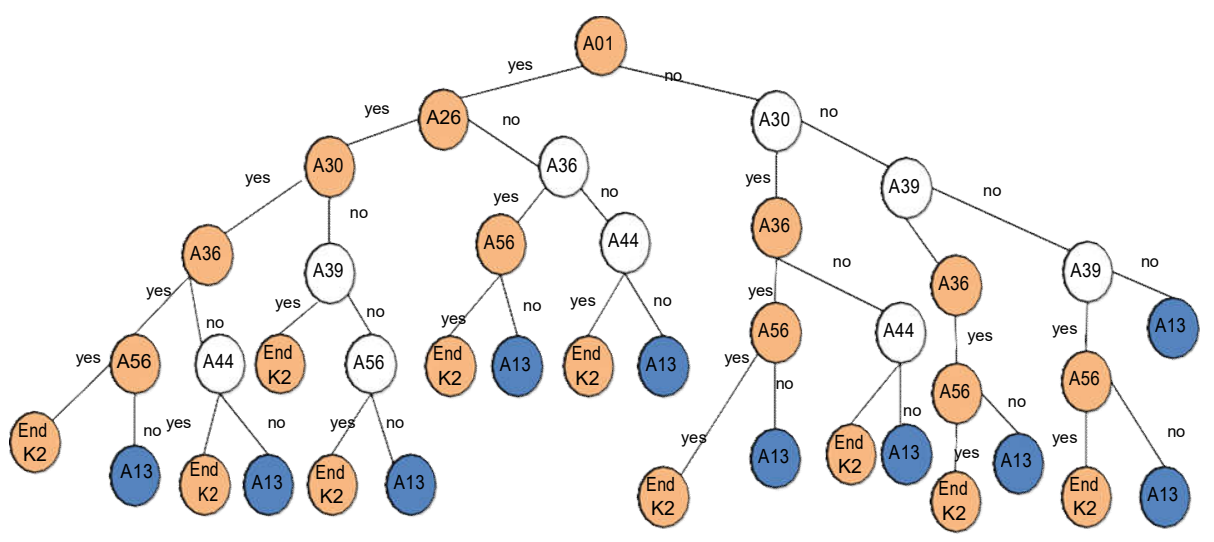

Gambar 4.4 Alur Informasi Kecerdasan Logis

3. Alur Informasi Menentukan Kecerdasan Spasial

Aturan untuk mendapatkan Kecerdasan Spasial seperti gambar dibawah ini :

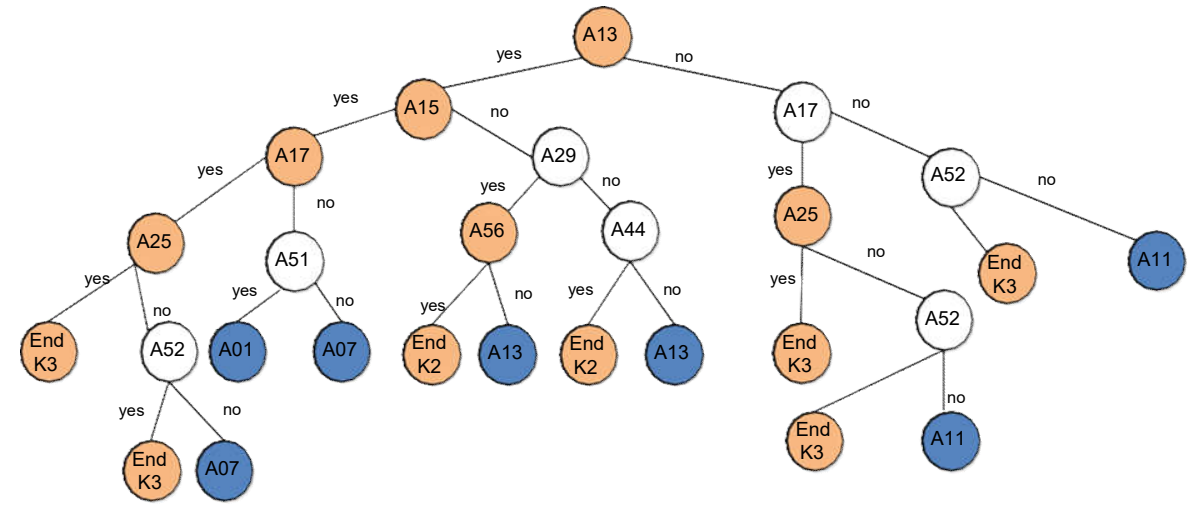

Gambar 4.5 Alur Informasi Kecerdasan Spasial

4. Alur Informasi Menentukan Kecerdasan Kinestik

Aturan untuk mendapatkan Kecerdasan Kinestik seperti gambar dibawah ini :

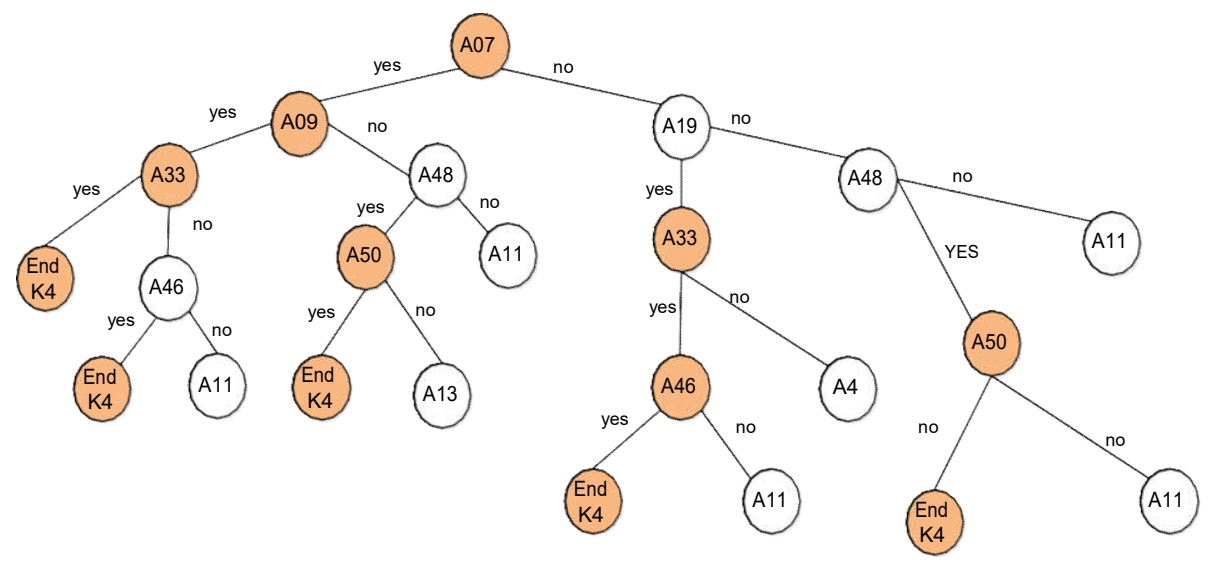

Gambar 4.6 Alur Informasi Kecerdasan Kinestik

5. Alur Informasi Menentukan Kecerdasan Antar Pribadi

Aturan untuk mendapatkan Kecerdasan Antar Pribadi seperti gambar dibawah ini : 


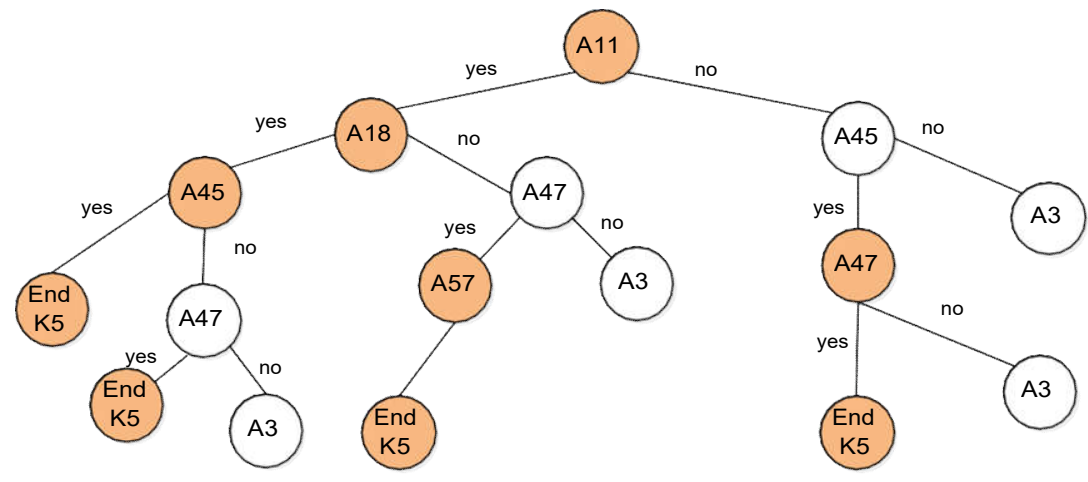

Gambar 4.7 Alur Informasi Kecerdasan Antar Pribadi

6. Alur Informasi Menentukan Kecerdasan Musikal

Aturan untuk mendapatkan Kecerdasan Musikal seperti gambar dibawah ini :

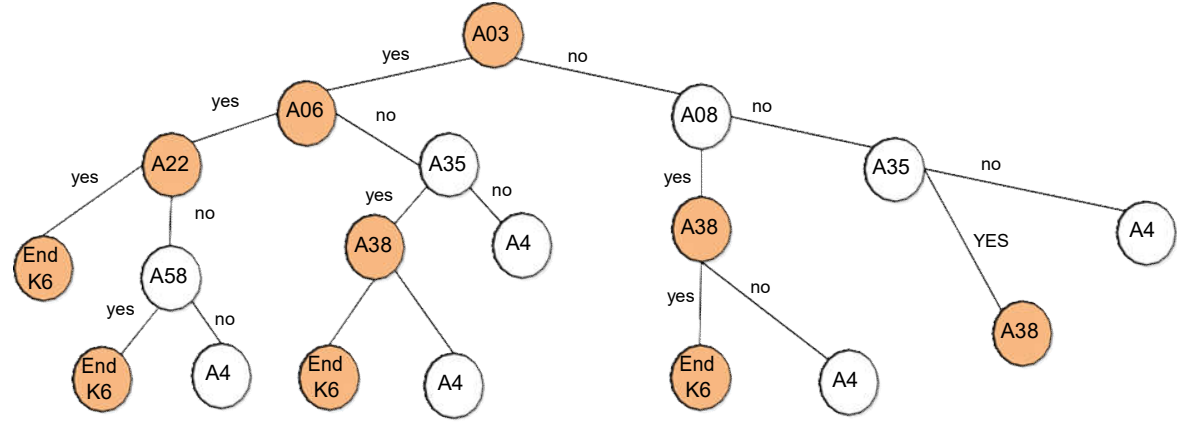

Gambar 4.8 Alur Informasi Kecerdasan Musikal

7. Alur Informasi Menentukan Kecerdasan Intra Antar Pribadi

Aturan untuk mendapatkan Kecerdasan Intra Antar Pribadi seperti gambar dibawah ini :

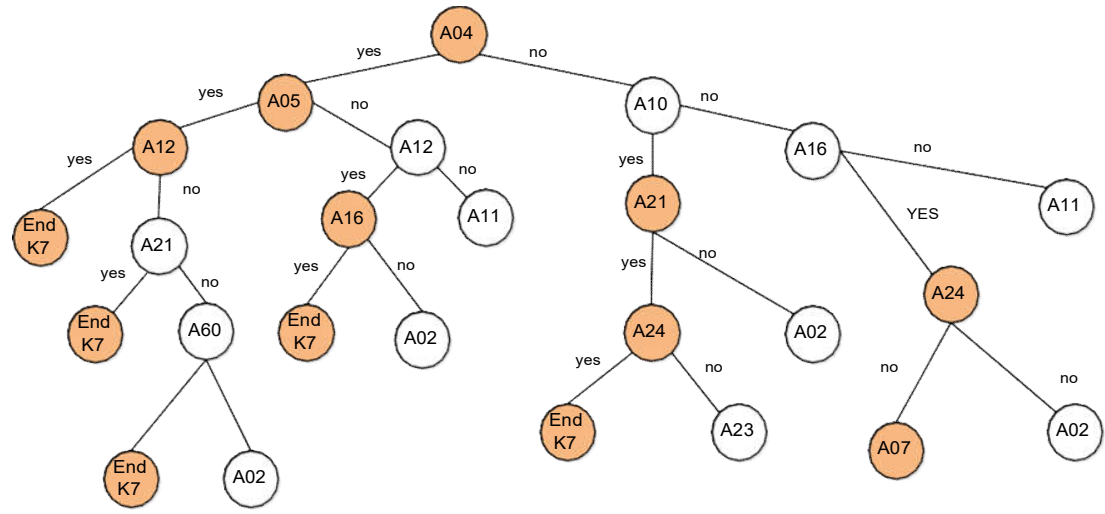

\section{Gambar 4.9 Alur Informasi Kecerdasan Intra Antar Pribadi}

8. Alur Informasi Menentukan Kecerdasan Naturalis

Aturan untuk mendapatkan Kecerdasan Naturalis seperti gambar dibawah ini : 


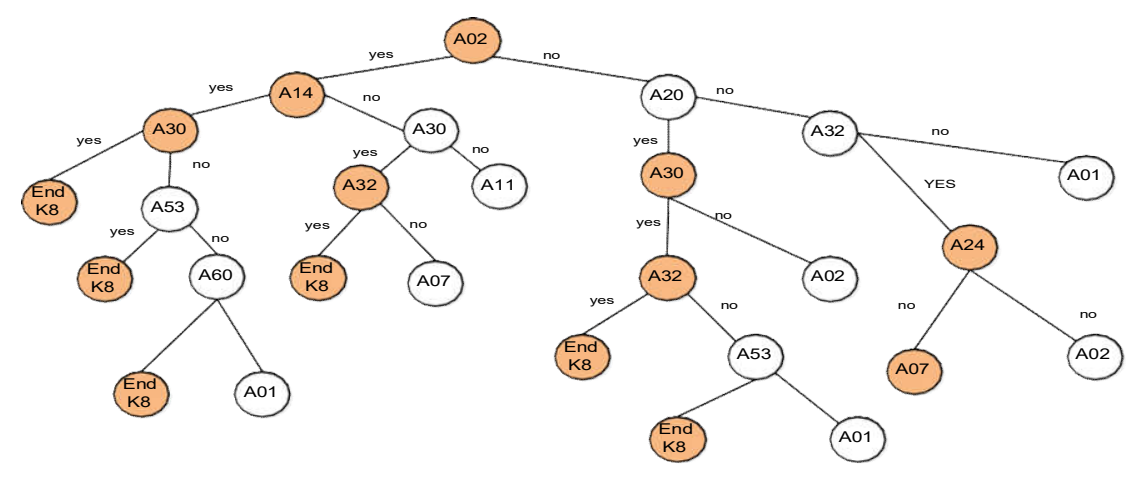

\section{Gambar 4.10 Alur Informasi Kecerdasan Naturalis}

\section{Perancangan Antarmuka}

Untuk memudahkan pengoperasian sistem ini, maka rancangan antar muka dibagi atas beberapa jenis, yang disesuaikan dengan fungsinya masing-masing yaitu:

\section{Tampilan Menu Utama}

Menu utama ini merupakan halaman dimana pertama kali membuka halaman web. Berikut ini tampilan menu utama.

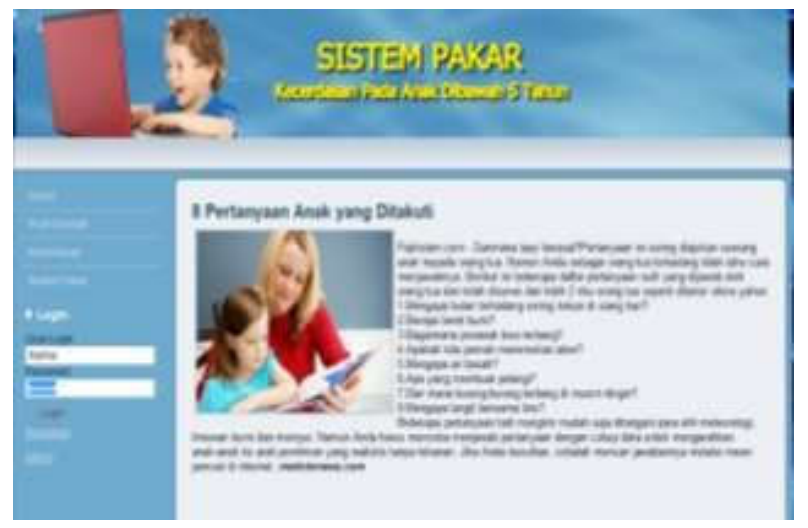

\section{Tampilan Form Login Admin}

Halaman login admin ini hanya diperuntukkan admin yang akan masuk ke sistem. Berikut ini adalah tampilan Form Login Admin.

\section{Gambar 5.1 Menu Utama}

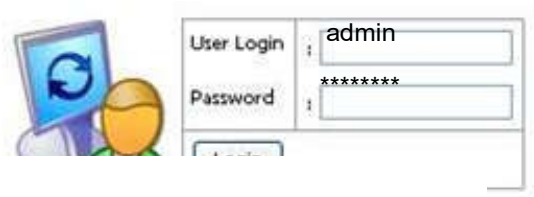

\section{Gambar 5.2 Form Login Admin}

\section{Tampilan Form Login User}

Halaman login dapat diakses disemua halaman, hal ini sengaja dilakukan untuk memudahkan user untuk masuk ke sistem pakar. Berikut ini adalah tampilan halaman login. 


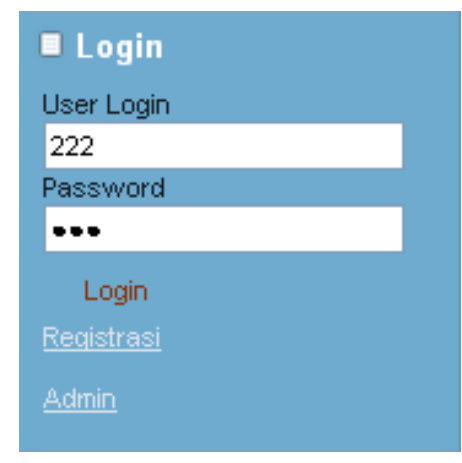

\section{Gambar 5.3 Form Login}

\section{Tampilan Form Registrasi}

Untuk bisa mengakses sistem pakar menentukan kecerdasan anak terlebih dahulu pasien mengisi Form Registrasi. Dengan tampilan sebagai berikut.

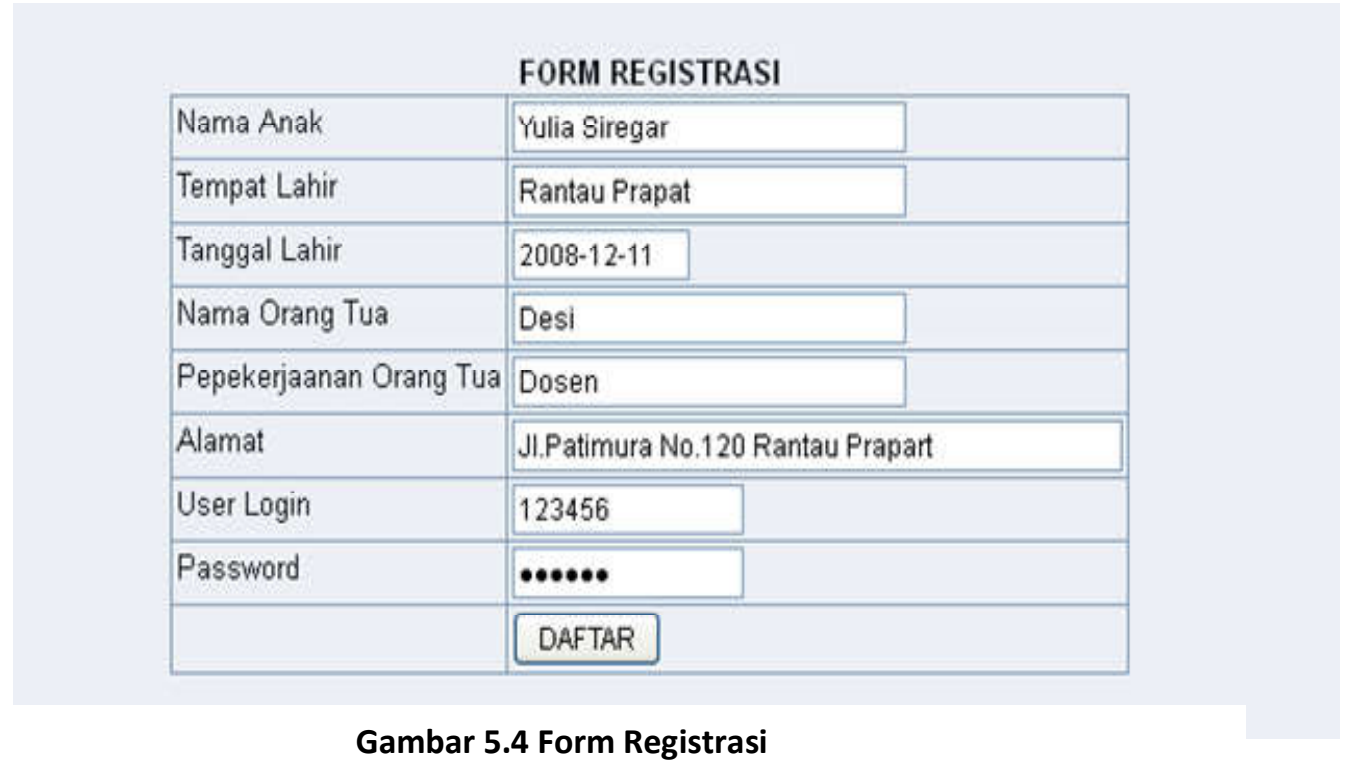

\section{Tampilan Halaman Diagnosa}

Setelah pasien registrasi, maka pasien diminta untuk menjawab beberapa pertanyaan tentang ciriciri yang dapat dilihat pada si anak, Berikut ini adalah tampilan dari halaman diagnosa.

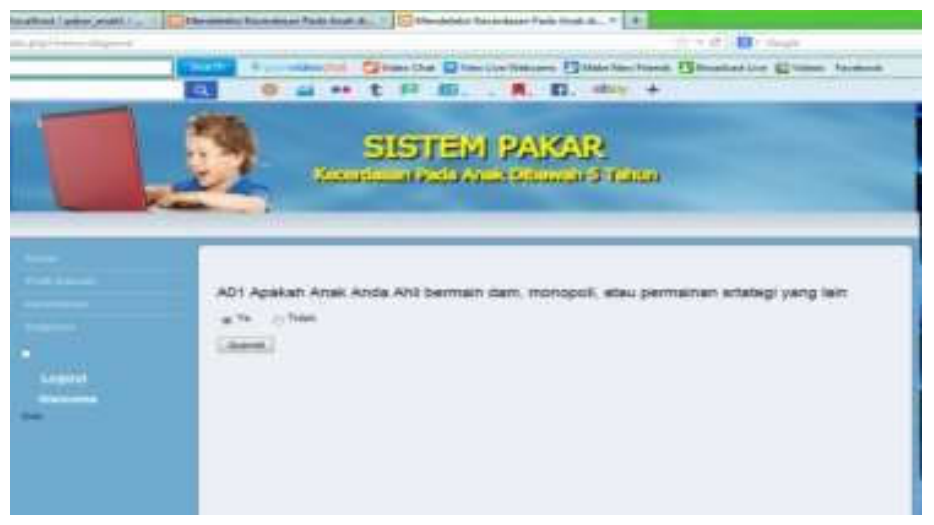

\subsubsection{Tampilan Hasil Diagnosa}

Gambar 5.5 Form Dialog Pertanyaan 
Setelah user memasukkan ciri-ciri yang ada pada anak, kemudian sistem pakar akan menampilkan hasil diagnosa, berupa jawaban jenis kecerdasan yang dimiliki oleh anak. Berikut ini adalah tampilan untuk hasil diagnosa.

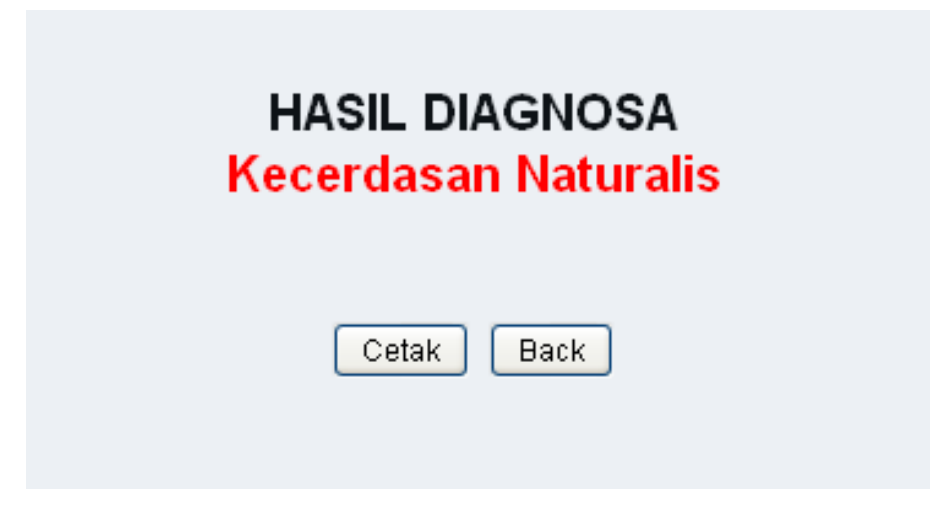

Gambar 5.6 Form Diagnosa

\subsubsection{Cetak Diangosa}

Setelah user mendapatkan hasil diagnose tentang kecerdasan pada anaknya, kemudian ada dialog cetak atau batal.

\section{HASIL DIAGNOSA \\ Kecerdasan Naturalis}

Cetak Back

\section{Gambar 5.7 Hasil Diagnosa}

diantaranya, Data, Laporan, dan Logout. Berikut ini adalah tampilah untuk Form home admin.

pa pilihan

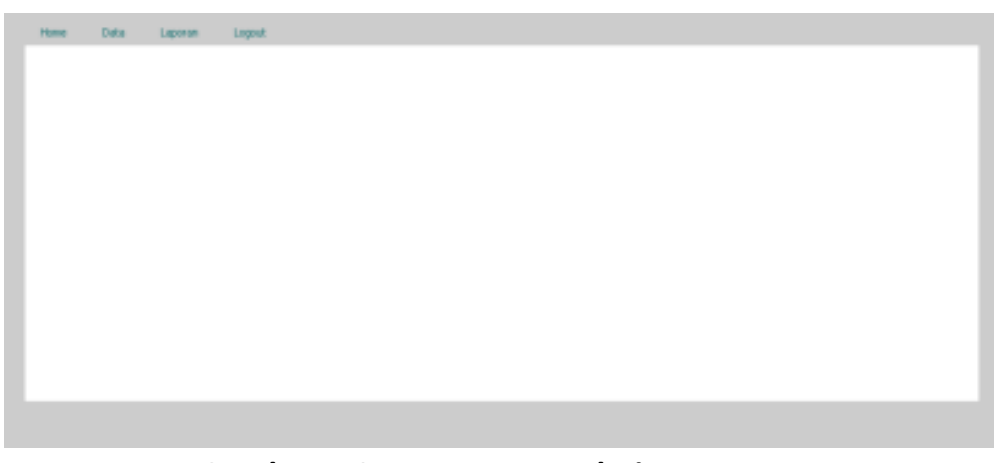

\section{Gambar 5.8 Form Home Admin}

\section{Tampilan Form Data}

Form data ini berisi data-data yang akan di input oleh admin. Ada tiga data yang akan di input oleh admin yaitu, kecerdasan, ciri-ciri, dan rule. 


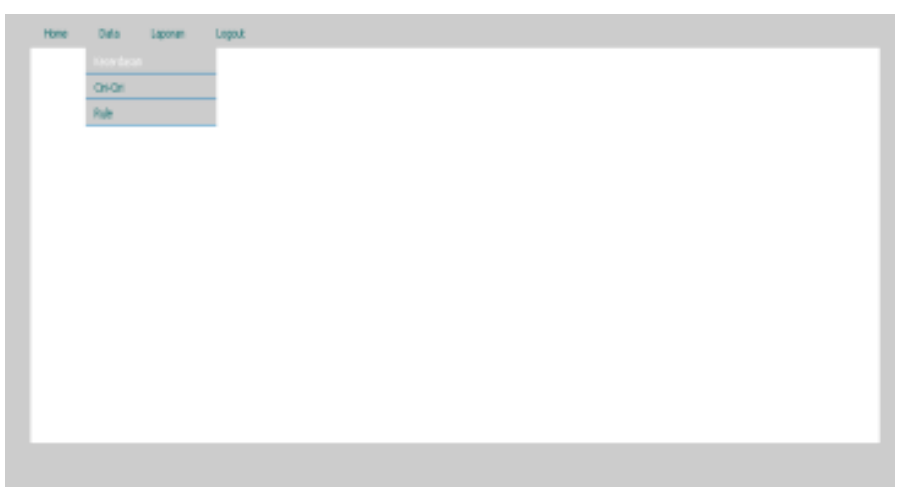

\section{Gambar 5.9 Form Data}

\section{Tampilan Form Kecerdasan}

Form ini digunakan admin untuk menginput data tentang macam kecerdasan anak. Berikut tampilan form kecerdasan.

\begin{tabular}{|l|l|c|c|}
\hline \multicolumn{4}{|c|}{ KECERDASAN Tambah } \\
\hline KODE & KECERDASAN & TDIT & DELETE \\
\hline K1 & Kecerdasan Linguistik & \\
\hline K2 & Kecerdasan Lagis & \\
\hline K3 & Kecerdasan Spasial & \\
\hline K4 & Kecerdasan Kinestetik & \\
\hline K5 & Kecerdasan Musikal & \\
\hline K6 & Kecerdasan Antar Pribadi & \\
\hline K7 & kecerdasan Intra Pribadi & \\
\hline K8 & Kecerdasan Naturalis & \\
\hline
\end{tabular}

\section{Gambar 5.10 Form Kecerdasan}

input tambah data kecerdasan.

\begin{tabular}{|l|l|}
\hline \multicolumn{2}{|c|}{ TAMBAH KECERDASAN } \\
\hline Kode & $\mathrm{K} 1$ \\
\hline Kecerdasan & Kecerdasan Linguistik \\
\hline & Simpan \\
\hline
\end{tabular}

\section{Gambar 5.11 Tambah Data Kecerdasan}

\section{Tampilan Form Ciri}

Form ini digunakan admin untuk menginput ciri-ciri pada anak. Berikut tampilan form ciri. 


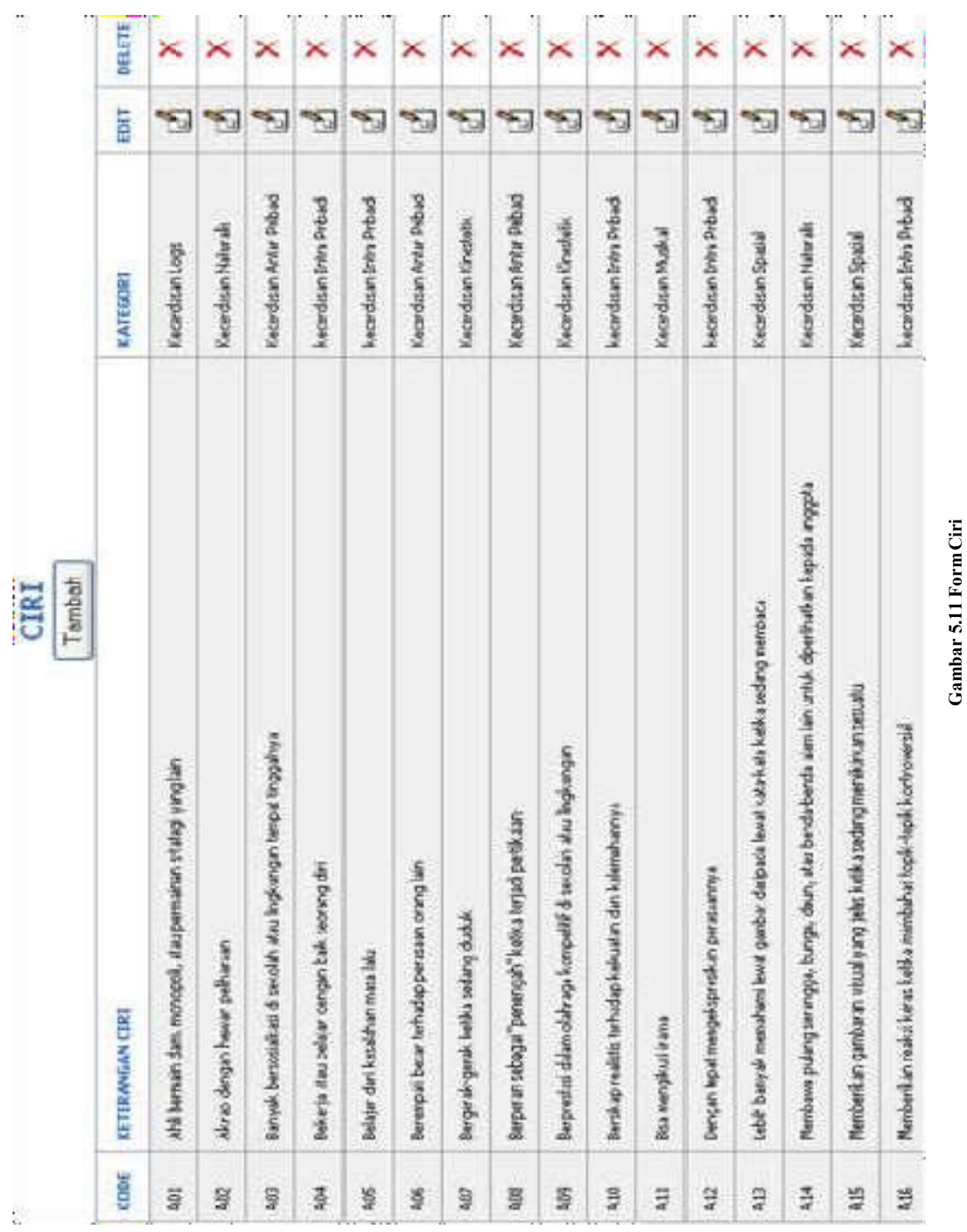

Pada form ini admin juga bisa menambahkan ciri-ciri pada anak. Berikut tampilan form untuk input tambah ciri-ciri.

\begin{tabular}{|l|l|}
\hline \multicolumn{2}{|c|}{ TAMBAH CIRI-CIRI } \\
\hline Kode Cini & A66 \\
\hline \multirow{3}{*}{ Nama Giri } & Mempunyai kosa kata yang luas untuk anak seusianya \\
\cline { 2 - 2 } & \\
\hline Kecerdasan & Kecerdasan Linguistik \\
\hline & Simpan Batal \\
\hline
\end{tabular}

Gambar 5.13 Form Tambah Ciri

\section{Tampilan Form Rule}

Form ini digunakan admin untuk menginput rule untuk menentukan kecerdasan pada anak. Berikut tampilan form rule. 


\begin{tabular}{|c|c|c|c|c|c|c|c|c|}
\hline \multicolumn{9}{|c|}{ Dinta biLE } \\
\hline no & $\begin{array}{l}\text { KODE } \\
\text { RULE }\end{array}$ & $\begin{array}{l}\text { KODE } \\
\text { CIRI }\end{array}$ & NaMA CIF! & YA & TBAK & KECERDASAN & EDIT & HAPUS \\
\hline 1 & 100 & A23 & Mempunyai kosaketa yang luas untuk andir seusianya & A27 & $A 28$ & $\begin{array}{l}\text { Kecerdasen } \\
\text { Linguratik }\end{array}$ & Eait & Hapus \\
\hline 2 & 110 & A27 & Mengarang kisah khayal atau menutukan letucen sax centa & N34 & A41 & $\begin{array}{l}\text { Kecendasan } \\
\text { Einguiesie }\end{array}$ & Eat & Hapus \\
\hline 3 & 120 & $A 28$ & Mengeja kxa-katadengan tegat dan modah & A34 & A5e & $\begin{array}{l}\text { Kocerdasan } \\
\text { Linguistik: }\end{array}$ & Eot & Hapus \\
\hline 4 & 130 & A34 & Menkemiai marrbaca bebu di wablu senggang & AS5 & A01 & $\begin{array}{l}\text { Kecterdasan } \\
\text { Unguistik }\end{array}$ & Eat & Hapus \\
\hline 5 & 140 & A41 & Menyukai pernainan kata & end & Aat & $\begin{array}{l}\text { Kocerdasar } \\
\text { Linguistik: }\end{array}$ & Eait & Hapus \\
\hline 6 & 150 & Ne & Suka mengisi teka taki silang & end & Not & $\begin{array}{l}\text { Koceedasan } \\
\text { Unguistic: }\end{array}$ & Edat & Hapus \\
\hline 7 & 160 & $A 55$ & Suka menulis kiextif di rumah & end & A01 & $\begin{array}{l}\text { Kosendasm } \\
\text { Linguistik }\end{array}$ & Eort & Hapus \\
\hline 8 & 170 & A01 & Ahil bermain dam, monopoli, wau pemsinan sitategi yang lan. & A. $\mathrm{F}$ & $A 30$ & Kacendasan Log:s & Eat & Hapuie \\
\hline 9 & 100 & A2S: & 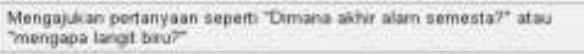 & A30 & As: & Koceedaban Logis & Eat & Hapus \\
\hline 10 & 190 & $A 00$ & Menghabiskan waitu dekat shuacum, atau sistem ketidypan lsain & $A 36$ & $\$ 9$ & Kecerdssan Logis & Edit & Hapus \\
\hline 11 & 200 & $A B S$ & Menkikmoni manggunakan hatiasa konpiater: & AEE & Ass: & Whesedakan Logia & Eat & Hapus \\
\hline 12 & 210 & $A 39$ & Menjolaskan mandiah aecara bogs & and & Nes & Kocordaoan Logis & Eat & Hapus \\
\hline 13 & 220 & Aes & Mudah membacs psta, grvik, den dagrkm & end & $A 13$ & Kecerdssan Loges & Eotit & Hapus \\
\hline 14 & 230 & ASE & Suka manyusun dalam kategan arau hieraiki & and & A13 & Kacedason Logis & Eat & Hapus \\
\hline 15 & 240 & $A 13$ & $\begin{array}{l}\text { Leob banyak memahami lewat gambar daripada lewal kats k kta ketika } \\
\text { sodang memtaca }\end{array}$ & A15 & A17 & Kocendatan Spatia & Eat & Hapus \\
\hline th & $2 \times n$ & $\Delta x$ & Membenikan gambarm vesual yand jelas ketika sedang memikitkan & a+7 & 400 & We-enturan Sinseiv & Fad & Hanni: \\
\hline
\end{tabular}

\section{Gambar 5.14 Form Rule}

Pada form ini admin juga bisa menambahkan rule untuk menentukan kecerdasan pada anak. Berikut tampilan form untuk input tambah rule.

INPUT DATA RULE

\begin{tabular}{|c|c|c|c|}
\hline KODE RULE & 640 & & \\
\hline$C|R|$ & -ciri- & & v \\
\hline YA & $-Y_{a-}$ & & $v$ \\
\hline TIDAK & -Tidak- & & $v$ \\
\hline \multirow[t]{2}{*}{ KECERDASAN } & -Kecerdasan- & $v$ & \\
\hline & Simpan ] Batal & & \\
\hline
\end{tabular}

Gambar 5.15 Form Tambah Rule

\section{Tampilan Form Pengunjung}

Form ini merupakan hasil laporan admin untuk melihat data pengunjung atau pasien yang pernah telah registrasi. Berikut tampilan form untuk laporan pengunjung.

\begin{tabular}{|c|c|c|c|c|c|}
\hline \multicolumn{6}{|c|}{ PENGUNUUUNG } \\
\hline no & USER LOGIM & MAMA & TEMPAT LAHIR & TGL LAHIR & ALAMAT \\
\hline 1 & Salma & Salma & Rantauprapat & $2009-01-21$ & Jin.Dewi Sartika \\
\hline 2 & Dara & Dara Esmalinda & Rantauprapat & $2009-05-01$ & Jin.AR.Hakim \\
\hline 3 & Fikra & Fikra Adtia & Medan & $2009-10-15$ & Jin.Ika Bina Kp.Baru \\
\hline 4 & Evan & Evan Agung Pramana & Rantauprapat & $2009-04-05$ & Jin.KP.Baru \\
\hline 5 & Revalina & Revalina Darman & Blok Songo & $2009 \cdot 09-03$ & Jin.Padang Bulan \\
\hline 6 & Zazkia & Zazkias Sarri Dewdi & Rantauprapat & $2009-10-02$ & Jin.Tenis \\
\hline 7 & Abdul & Abdul Kharim Munthe & Rantauprapat & $2009-06 \cdot 30$ & Jin.Ahmad Yani \\
\hline 8 & Umul & Umul Pairi & Gunung Sari & $2009-10-21$ & Jin.Dewi Sartika \\
\hline 9 & Dwi Ningsih & Dwi & Rantauprapat & $2009-11-27$ & Jin. Thamrin \\
\hline 10 & Agus & Agustian aRez & Sigambal & $2009-05-03$ & Jin.Sigambal \\
\hline 11 & Putri & Putri Ananda RIzki & Rantauprapat & $2007 \cdot 01-20$ & Jin.Ika Bina Kp.Baru \\
\hline 12 & Ardina & Ardina Salsablah & Medan & $2009-01-11$ & Jin.Rantau Lama \\
\hline 13 & Nazwan & Nazwan Syahputra & Rantauprapat & $2009-07-16$ & Jn.Batu Sangkar \\
\hline 14 & Evi & Evi Julia Fitri & Rantauprapat & $2009-02-24$ & Jin.Kp. Baru \\
\hline 15 & sri & Sri Iswahyuni & Rantauprapat & $2009-07-06$ & Jin.Sirandorung \\
\hline 16 & Ami & Ami Syahputra & Rantauprapat & $2009-06-16$ & Jin.Siringo-ringo \\
\hline 17 & Yulia & Yulana Fitri & Rantauprapat & $2009-03-12$ & Jin.Ika Bina Ko.Garu \\
\hline 18 & Nanda & Nanda Pramana & Rantauprapat & $2009-11 \cdot 10$ & Jin.Sirngo-ringo \\
\hline 19 & Aulia & Aula Zahra & Rantauprapat & $2009-10-07$ & Jin.Ika Bina Kp.Baru \\
\hline 20 & Reky & Rizky Aula & Marbau & $2009-03-03$ & Jin.Paindoan \\
\hline 21 & Budi & Budi Atmanda Putra & Rantauprapst & $2009-01-11$ & Ji.Sudiman \\
\hline
\end{tabular}




\section{Gambar 5.16 Laporan Pengunjung}

\section{Tampilan Form Penelusuran}

Form ini merupakan hasil laporan admin untuk melihat hasil yang diperoleh oleh pengunjung atau pasien yang pernah telah melakukan diagnosa. Berikut tampilan form untuk laporan penelusuran.

HASIL PENELUSURAN SISTEM KECERDASAN ANAK

\begin{tabular}{|c|c|c|c|c|c|}
\hline NO & TGL & NAMA & ALAMAT & TGL LAHIR & HASIL \\
\hline 1 & 30 Agustus 2013 & Salma & Jln.Dewi Sartika & 21 Januari 2009 & Kecerdasan Linguistik \\
\hline 2 & 05 September 2013 & Dara Esmalinda & Jln,AR.Hakim & $01 \mathrm{Mei} 2009$ & Kecerdasan Kinestetik \\
\hline 3 & 07 September 2013 & Fikra Aditia & Jln.Ika Bina Kp.Baru & 15 Oktober 2009 & Kecerdasan Naturalis \\
\hline 4 & 07 September 2013 & Evan Agung Pramana & Jln,KP,Baru & 05 April 2009 & Kecerdasan Spasial \\
\hline 5 & 06 September 2013 & Umul Pairi & Jln.Devi Sartika & 21 Oktober 2009 & Kecerdasan Antar Pribadi \\
\hline 6 & 05 September 2013 & Agustian aRez & Jln,Sigambal & 03 Mei 2009 & Kecerdasan Naturalis \\
\hline 7 & 05 September 2013 & Putri Ananda RIzki & Jln.Ika Bina Kp. Baru & 20 Januari 2007 & Kecerdasan Logis \\
\hline 8 & 07 September 2013 & Nazwan Syahputra & Jln, Batu Sangkar & 16 Juli 2009 & kecerdasan Intra Pribadi \\
\hline 9 & 07 September 2013 & Evi Julia Fitri & Jln.Kp,Baru & 24 Februari 2009 & Kecerdasan Antar Pribadi \\
\hline 10 & 07 September 2013 & Sri Iswahyuni & Jln.Sirandorung & 06 Juli 2009 & Kecerdasan Logis \\
\hline 11 & 07 September 2013 & Yuliana Fitri & Jln.Ika Bina Kp.Baru & 12 Maret 2009 & Kecerdasan Musikal \\
\hline 12 & 07 September 2013 & Nanda Pramana & Jln,Siringo-ringo & 10 November 2009 & Kecerdasan Kinestet \\
\hline 13 & 30 Agustus 2013 & Budi Atmanda Putra & Jl,Sudirman & 11 Januari 2009 & Kecerdasan Kinestet \\
\hline
\end{tabular}

\section{Gambar 5.17 Hasil Penelusuran}

\section{V.KESIMPULAN DAN SARAN}

\section{Kesimpulan}

Berdasarkan penelitian dan pembahasan yang dilakukan, maka dapat disimpulkan beberapa hal sebagai berikut :

1. Program yang berbasis sistem pakar ini, sangat memberikan kemudahan kepada para psikolog dan para orang tua untuk mengetahui kecerdasan pada anak sesuai dengan konseptual ilmu pengetahuan psikologi.

2. Sistem yang beranalisa penelusuran kecerdasan pada anak ini sangat sesuai dengan metode Forward Chaining. Hal ini terbukti dengan tidak adanya kendala yang signifikan dalam penyusunan sistem ini, dan knowledge yang dihasilkan sistem ini juga sesuai dengan penelusuran secara manual.

3. Walaupun sistem ini telah dirancangan semaksimal mungkin, penulis menyadari masih ada kelemahan yaitu tidak permanennya ketentuan-ketentuan pilihan yang akan menjadi acuan penelusuran sistem.

Perkembangan ilmu Psikologi sangat dibutuhkan dalam percancangan sistem ini. Jadi ketika terjadi perkembangan ilmu psikologi, maka rule-rule pada sistem ini akan selalu dirubah.

\section{Saran-saran}

Sebagai akhir dari penelitian ini, peneliti ingin menyampaikan saran-saran yang mungkin bermanfaat bagi siapa saja yang berminat untuk menggunakan sistem ini.

1. Rancangan sistem pakar untuk penelusuran kecerdasan anak ini, penulis rasakan masih jauh dari kesempurnaan, untuk itu pernulis mengharapkan ada pihak atau peneliti lain yang mau mengembangkan dan melanjutkan penelitian ini. 
2. Untuk mendapakan hasil penelusuran yang lebih akurat dan lebih mendekati kebenaran sebaiknya diterapkan metoda-metoda statistik atau metoda sistem pengambilan keputusan lainnya yang sesuai dengan perkembangan ilmu psikologi yang ada.

3. Kepada para pemakai diharapkan dapat mengembangkan sistem ini sesuai dengan keinginan dan kegunaannya, karena sistem ini dibuat secara fleksibel dan dapat dirubah khusus bagi pengguna sebagai pakar dan admin.

\section{DAFTAR PUSTAKA}

Sri Kusumadewi, Artificial Intellegence, Yogyakarta, 2003.

Feri Fahrur Rohman, Ami Fauzijah, Rancangan Bangun Aplikasi Sistem Pakar Untuk Menentukan Jenis Gangguan Perkembangan Pada Anak, Yogyakarta, 2008.

Muhammad Ahrami, Merancang Dan Membuat Sistem Pakar, Fakultas Teknologi Informasi, Universitas Stikubank, Semarang, 2005.

Hersatoto Listiyono, Merancang dan Membuat Sistem Pakar, Fakultas Teknologi Informasi, Universitas Stikubank, Semarang, 2008.

Muhammad Dahria et. All, Sistem Pakar Metode Damster Shafer Untuk Menentukan Jenis Gangguan Perkembangan Pada Anak, Program Studi Sistem Informasi, STMIK Triguna Dharma, Medan.

Kusumadewi, Rancang Bangun Aplikasi Sistem Pakar Untuk Menentukan Jenis Gangguan Perkembangan Pada Anak, 2003

Turban, Rancang Bangun Aplikasi Sistem Pakar Untuk Menentukan Jenis Gangguan Perkembangan Pada Anak, 2006.

Tati Harihayati, Luthfi Kurnia, Sistem Pakar Mendiagnosa Penyakit Umum Yang Sering Diderita Balita Berbasis Web Di Dinas Kesehatan Kota Bandung, Bandung, 2012.

Russel P, Penerapan Metode Forward Chaining Pada Aplikasi Sistem Pakar Berbasis Web Untuk Diagnosa Gangguan Ketidakseimbangan Asam/Basa Pada Manusia, 2003.

Riskadewi dan Antonius Hendrik, Penerapan Sistem Pakar Forward ChainingBerbasis Aturan Pada Pengawasan Status Penerbangan, Bandung, 2005.
Conny Semiawan, Kecerdasan Dan Perkembangan Otak, Yogyakarta, 1999: 114.

Helms dan Turner, Kecerdasan Dan Perkembangan Otak, Yogyakarta, 1981: 142.

Cratty, Kecerdasan Dan Perkembangan Otak, Yogyakarta, 1986: 29-30.

Chaterine Syarif, Menjadi Pinta Dengan Otak Tengah, Yogyakarta, 2010.

Urie Bronfrenbrenner dan Ann Crouter, Psikologi Perkembangan Anak Dan Remaja, Bandung, 1995.

Ebrahim GJ, Tumbih Kembang Anak, Surabaya, 1985.

AAHPERD, Mengembangkan Kecerdasan Anak Melalui Kegiatan Out Bound, Yogyakarta, 1999: 169-171. 